\title{
Comparing The Productive and Economic Efficiency of Some Freshwater Fish Farms in El Sharkia, Ismailia, and Kafr El Sheikh
}

\author{
Mohamed Osman ${ }^{\mathrm{a}}$, Mohamed Abou El Atta ${ }^{\mathrm{b}}$, Manal Mohamed ${ }^{\mathrm{b}}$, \\ Mostafa Mandoura \\ ${ }^{a}$ Faculty of Veterinary Medicine, Suez Canal University, Ismailia, Egypt \\ ${ }^{b}$ Central Laboratory for Aquaculture Research, El Abbassa, Sharkia, Egypt
}

\begin{abstract}
This research aimed to study the efficiency of freshwater fish farms among three governorates: El Sharkia, Ismailia, and Kafr El Sheikh during the period 2015 and 2016. Data of productive and economic parameters of 64 freshwater fish farms were investigated through farm records in addition to research questionnaire. One-way ANOVA procedure was fitted. All statistical analyses were carried out by SPSS for windows. The current study showed that farm locality has a notable effect on the productive and economic parameters of freshwater fish farms. Regarding total fish production, Kafr El Sheikh governorate had the highest quantity of fish production, while El Sharkia was the lowest. From the results of analysis of locality effect on economic efficiency parameters (TC, TR and NP (EGP)/kg), it was concluded that although El Sharkia governorate had the highest value of total cost (16.34 EGP) and Kafr El Sheikh governorate had the lowest one (13.12 EGP), the highest profit recorded was in El Sharkia governorate (9.01 EGP). It is strongly recommended to encourage the government to invest more in aquaculture production in studied areas as the aquaculture was reported to be a profitable business in these.
\end{abstract}

Keywords: Aquaculture, fish, economics, efficiency

\section{Introduction}

The increasing population in Egypt is one of the most important contemporary problems, especially with the widening gap between local food production and consumption. Such increase has negative effects on economic development and on provision of food for the poor in terms of quantity, quality and prices.
Developing plans aimed at narrowing this gap by increasing food supply in general and animal protein in particular. The fish sector is considered the promising sectors for food security and economic development of Egypt (Soliman and Yacout, 2016). Egypt is currently facing significant constraints in fisheries production with high prices 
of wild fish which necessitate growth in aquaculture sector.

A high increase in aquaculture production was observed during the last 10 years. In 2015, aquaculture production had reached 1174831 tones representing a $3.32 \%$ increase than 2014. On the other hand fish production income represented $9.07 \%$ of the total agricultural income which was 20298 million Egyptian Pounds (EGP) (GAFRD, 2017). Despite the increase in aquaculture production, many constraints exist for its full exploitation such as random place of ponds, poor design, high rent of land, fry shortage, high cost of feed, and management problems (GAFRD, 2009). Thus the aim of this study is to economically evaluate some freshwater fish farms in Egypt by evaluating production costs and revenues received.

\section{Materials and Methods}

Data of 64 freshwater fish farms raising tilapia (Oreochromis niloticus), mullet (Mugil cephalus), and topar (Liza ramada) were collected during 2015 and 2016 from 3 Governorates: El Sharkia, Ismailia, and Kafr El Sheikh. Data were obtained from farm records in addition to a designed research questionnaire. The analysis was done for the production inputs including the amount of feed consumed, prices of feed, labour costs, fingerlings cost, mortality rate and total production (kg); also for costs parameters including total variable cost (TVC), total fixed cost (TFC), and total cost (TC). The returns parameters include total return (TR) calculated by multiplying quantity produced $(\mathrm{kg}) \times$ price/kg. The net profit (NP) was calculated by subtracting TC from TR. Analysis of variance was done to fulfill the equation: $V_{i j k}=\mu+S_{i}+L_{j}$ $+\mathrm{e}_{\mathrm{ijk}}\left(\mathrm{V}_{\mathrm{ijk}}=\right.$ An observed value, $\mu=$ overall mean, $S_{i}=$ Effect due to the $I^{\text {th }}$ year $(2015,2016), L_{j}=$ Effect due to the $\mathrm{J}^{\text {th }}$ locations (El Sharkia, Ismailia, Kafr El-sheikh), $\mathrm{e}_{\mathrm{ijk}}=$ error). Efficiency measures of cost and return parameters per each feddan, live $\mathrm{kg}$, and per 1000 fingerlings were calculated according to (Mandour, 2013).

\section{Results and Discussion}

1-Effect on pond size, total farm area (feddan), rent per feddan (EGP):

Data recorded in Table (1) showed the pond size, total farm area, rent per feddan, and total rent. The pond area was not-significantly different $(\mathrm{P}>0.05)$ among governorates but was significantly different $(\mathrm{P}<0.05)$ through the study period. The highest mean value for pond area was found in EL Sharkia (5.30 feddan), while the lowest value was found in Ismailia (4.29 feddan). Also, found that the highest mean value was in 2015 (6.64 feddan) compared to 2016 (4.63 feddan). In regards to the total farm area, there was significant difference $\quad(\mathrm{P}<0.05) \quad$ among governorates, also between years. The highest mean value was found in Kafr El Sheikh (66.67 feddan), while 
the lowest value was found in $\mathrm{El}$ Sharkia (37.42 feddan), also the highest mean value was found in 2015 (85.71 feddan), while the lowest value was found in 2016 (42.43 feddan).

Regarding to rent per feddan, Nosignificant difference $(\mathrm{P}>0.05)$ was found for the rent per feddan between years, but was significantly different $(\mathrm{P}<0.05)$ among governorates and also among years. The highest mean value in Kafr El- Sheikh (6416.67 EGP), while the lowest value found in Ismailia (2647.06 EGP), the highest value recorded at 2015 (3928.57 EGP), also the lowest value recorded at 2016 (3568.42 EGP). This agreed with $(\boldsymbol{G A F R D , 2 0 1 7 )}$ who stated that Kafr El-sheikh has more production than other governorates which might be attributed to large areas used for aquaculture production. Also, agreed with Hafsa et al. (2012) who stated that increasing of pond size will increase fish production. Also, with Aly (2006) who showed that economic and productive efficiency of fish farms are affected by pond size and farm location.

2- Effect on stocking density/feddan and total number of fingerlings stocked among governorates and years

Data recorded in Table (2) showed the differences in stocking density of tilapia fingerlings was nonsignificantly different through the study period where the highest value recorded at 2015 (11285), also the lowest value recorded at 2016 (10403); but significantly differed $(\mathrm{P}<0.05)$ among governorates. Tilapia fingerlings number/feddan was highest in Kafr El- Sheikh (14166), while the lowest value found in El Sharkia (9428). Mullet fingerlings stocking density was nonsignificantly different through the study period where the highest value recorded at 2015 (871), also the lowest value recorded at 2016 (857); but significantly differed $(\mathrm{P}<0.05)$ among governorates. The highest mean value in El Sharkia (1032), while the lowest value found in Kafr El Sheihk (633). In regards to topar fingerlings number/feddan, it was evident that there was no significant difference $\quad(\mathrm{P}>0.05) \quad$ among governorates or years. The highest mean value was in El Sharkia (1900), while the lowest value found in Ismailia (1470). The highest value recorded at 2016 (1754), also the lowest value recorded at 2015 (1428). A significant difference $(\mathrm{P}<0.05)$ of total fishes stocked $\left(\times 10^{3}\right)$ through the study period and localities, as Kafr El Sheikh has the highest stocking density 1108.58 compared to Ismailia and El Sahrkia Governorate (710.05 and 487.55; respectively. Stocking density had decreased in 2016 to reach 596.50 compared to 2015 (1205.42). This might be due to differences in farmers' experience. This agreed with Bhujel (2014) who reported that farmer's experience effect on number of fish stocked and species cultured. 
Also, with Alam et al. (2012) who reported variation in production practices among farmers.

3-Effect on price (EGP)/1000 fingerlings of fish stocked:

Results in Table (3) showed a significant difference $(\mathrm{P}<0.05)$ of the price/1000 fingerlings stocked through the study period and among localities. The price of 1000 tilapia fingerlings was found to be highest in El Sharkia (141.28), while the lowest value found in Kafr El Sheikh (82.50), the highest value recorded at 2016 (121.57 EGP), also the lowest value recorded at 2015 (106.42 EGP).This might be attributed the increase of fingerlings supply results in lowering the price; as there are many hatcheries in Kafr El Sheikh. As for mullet fingerlings, the highest mean value was in Kafr El Sheikh (2708.33 EGP), while the lowest value found in El Sharkia (1871.42EGP). The highest value recorded at 2016 (2229.82 EGP), also the lowest value recorded at 2015 (1628.5 EGP). The price of topar fingerlings was of highest mean value in Ismailia (1223.52 EGP), while the lowest value was in El Sharkia (574.28EGP), the highest value was at 2016 (859.64EGP), and the lowest value recorded at 2015 (571.42EGP). Total fingerlings cost (EGP) showed no significant difference among governorates and years. The highest mean value in Kafr El Sheikh (259370), while the lowest value found in El Sharkia (215277), the highest value recorded at 2015 (264214), also the lowest value recorded at 2016 (224932). Such variations might be attributed to differences in demand, supply, or size. This agreed with Bhujel (2014) who reported that bigger size of fish is more expensive than smaller size. Results agreed with Aamer (1986) who found that major part of production cost was fry cost representing $31 \%$ from TC and 63.5 $\%$ from TVC.

4-Effect on cost of fuel and transportation:

Data at Table (4) showed the effect on cost of fuel and transportation (EGP) which differed significantly $(\mathrm{P}<0.05)$ among governorates and years. The highest mean value for fuel cost in Kafr El Sheikh (47816.6), while the lowest value found in Ismailia (19970.5), the highest value recorded at 2015 (43571.4), also the lowest value recorded at 2016 (26242.1). The highest mean value for transportation was in El Sharkia (11411.4), while the lowest value found in Ismailia (1341.2), the highest value recorded at 2015 (15000), also the lowest value recorded at 2016 (7753.5). Results agreed with Macfadyen et al. (2011) who reported certain portion of total production costs is constituted by fuel and power. Also, all processes of aquaculture systems demand both fuel and power (Samuel-Fitwi et al. 2013). The CAPMAS (2014) reported that energy consumption increased by $25.9 \%$ due to increased aquaculture production from 2008 till 2011.

\section{5-Effect on total cost of feed:}


Data showed at Table (5) the effect on total feed (tons) and total cost of feed (EGP), which differed significantly among governorates and years. The highest mean value of total feed consumed was in Kafr El Sheikh (397.71 tons), while the lowest value found in El Sharkia (187.91 tons), and the highest value recorded at 2015 (438.86 tons), also the lowest value recorded at 2016 (220.69 tons). And also data showed total cost of feed where the highest mean value in Kafr El Sheikh (3287479 EGP), while the lowest value found in El Sharkia (1442697 EGP), the highest value recorded at 2015 (3232285 EGP), also the lowest value recorded at 2016 (1805469 EGP). The results were similar to those of Sikiru et al. (2009), they estimated feed cost as the main component in fish production. Macfadyen et al. (2011); Rothuis et al. (2013); and ElSayed (2014) found that rapid increase in the cost of fish feed was one of the main constraints faced by the fish feed industry and farmers. Also, Craig and Helfrich (2009) added that from $40-50 \%$ of total cost of fish production represented feed cost.

\section{6-Effect on labour cost:}

Data showed at Table (6) the significant effect $(\mathrm{P}<0.05)$ of governorate and year on labour costs (EGP) for all species. The highest mean value in Kafr El Sheihk (95940 EGP), while the lowest value found in El Sharkia (67691 EGP), the highest value recorded at 2015
(107077 EGP), also the lowest value recorded at 2016 (71006 EGP). Results agreed with Macfadyen et al. (2011) reported that labor costs represented about $8 \%$ of the operational costs. Also agreed with Bhujel (2014) who stated that labour cost is important factor that affect profit of fish farms.

\section{7-Effect on cost parameters:}

From the data in Table (7), it was evident that there were significantly different $(\mathrm{P}<0.05)$ in cost parameters: total fixed cost (TFC), total variable cost (TVC) and total cost (TC) among governorates and between years. TFC had the highest mean value in Kafr El Sheihk (528708 EGP), while the lowest value found in El Sharkia (172483 EGP), the highest value recorded at 2015 (496347 EGP), also the lowest value recorded at 2016 (220612 EGP). Also for TVC found the highest mean value in Kafr El Sheihk (3720502 EGP), while the lowest value found in El Sharkia (1727182 EGP), the highest value recorded at 2015 (3640605 EGP), also the lowest value recorded at 2016 (2108333 EGP). Finally for TC, the highest mean value in Kafr El Sheihk (4249210 EGP), while the lowest value found in El Sharkia (1899666 EGP), the highest value recorded at 2015 (4136953 EGP), also the lowest value recorded at 2016 (2328946 EGP). The TC was more in 2015 compared to 2016 (2328946 EGP). Results also indicated that Kafr el-sheikh has the highest total cost. These results are 
parallel to those of Aly (2006) who reported significant differences of Governorates on different costs. $\boldsymbol{E l}$ Naggar et al. (2006) found that an average farmer incurred a total sum of $316051 \mathrm{LE}$ as operational costs (OC) per feddan in season 2004-2005 in Behera governorate.

\section{8-Effect on mortality percentage:}

Data showed at Table (8) represented the mortality \% which was nonsignificant $(\mathrm{P}>0.05)$ among different localities and years. The highest mean value in Ismailia $(7.65 \%)$, while the lowest value found in $\mathrm{El}$ Sharkia $(6.86 \%)$, the highest value recorded at $2015(9.0 \%)$, also the lowest value recorded at 2016 $(6.96 \%)$. Results are in line with Yosra (2008) who found that disease incidence and consequently mortality differ among different areas and localities. Eissa et al. (2013) reported that fish ectoparasites caused serious diseases and high mortalities in fingerlings under stress condition.

9-Effect on total production (kg):

Data of Table (9) showed the effect on tilapia, mullet, and topar production $(\mathrm{kg})$. It was evident that there was significant difference $(\mathrm{P}<0.05)$ in total weight sold of tilapia. For mullet, it differed significantly among years. As for topar, it differed significantly among governorates. The highest production of tilapia sold in Kafr El Sheihk $(295075 \mathrm{~kg})$, while the lowest value found in El Sharkia (94848 kg), the highest value recorded at 2015 $(293614 \mathrm{~kg})$, also the lowest value recorded at $2016(136139 \mathrm{~kg})$. For mullet sold, the highest mean value in El Sharkia $(14754 \mathrm{~kg})$, while the lowest value found in Ismailia (10332 $\mathrm{kg}$ ), the highest value recorded at $2015(19195 \mathrm{~kg})$, also the lowest value recorded at $2016(11831 \mathrm{~kg})$. Also for topar sold found the highest mean value in El Sharkia (28276 kg), while the lowest value found in Ismailia (17041 kg), the highest value recorded at $2015(29220 \mathrm{~kg})$, also the lowest value recorded at 2016 (21935 $\mathrm{kg}$ ).

Finally for total weight of all fish sold found the highest mean value in $\mathrm{Kafr}$ El Sheihk (325770 kg), while the lowest value found in El Sharkia $(126648 \mathrm{~kg})$, the highest value recorded at $2015(333681 \mathrm{~kg})$, also the lowest value recorded at 2016 $(165371 \mathrm{~kg})$. This agreed with Craig and Helfrich (2009), they concluded that final fish weight sold will vary depending on multiple factors including environmental conditions and therefore localities. Also, ElNaggar et al. (2006) reported that an average quantity of fish produced in kilogramme is about 2635 per feddan in season 2004-2005 in Behera governorate.

\section{0-Effect on TR and NP (EGP):}

Data at Table (10) showed that total return (TR) and net profit (NP) (EGP) differed significantly $\quad(\mathrm{P}<0.05)$ among the different localities and years; but NP showed significant difference $(\mathrm{P}<0.05)$ among localities. The TR found the highest mean value in Kafr El Sheihk (6519045 EGP), while the lowest value found in El Sharkia (3178739 EGP), the highest 
value recorded at 2015 (6118785 EGP), also the lowest value recorded at 2016 (3933946 EGP). The NP found the highest mean value in Kafr El Sheihk (2269835 EGP), while the lowest value found in El Sharkia (1279072 EGP), the highest value recorded at 2015 (1981832 EGP), also the lowest value recorded at 2016 (1605000 EGP). These results had agreed with Azazy (2003) reporting significant differences $(\mathrm{P}<0.05)$ among areas based on species reared. Also, Macfadyen et al. (2011) reported that Kafer El Sheikh, Behera, Sharkia, and Fayoum are considered the major governorates in aquaculture sector in Egypt.

\section{1-Effect on TC, TR and NP (EGP)/fed:}

Data at Table (11) showed that TC/ feddan and TR / feddan differed significantly $(\mathrm{P}<0.05)$ among the different localities, years; as for the net profit/feddan (NP/Fed) (EGP) it was non-significantly different $(\mathrm{P}>0.05) \quad$ among different governorates; but significantly different among years. The highest mean value of TC/Fed was in Kafr El Sheihk (62725.8 EGP), while the lowest value found in Ismailia (45976.2 EGP), the highest value recorded at 2016 (54625.3 EGP), also the lowest value recorded at 2015 (43205.9 EGP).

Also for TR/Fed, the highest mean value in Kafr ElSheihk (96871.2 EGP), while the lowest value found in Ismailia (77161.4 EGP), the highest value recorded at 2016 (89118.6 EGP), also the lowest value recorded at 2015 (60307.2 EGP). Finally for NP/Fed found the highest mean value in Kafr El Sheihk (34145.4 EGP), while the lowest value found in Ismailia (31185.2 EGP), the highest value recorded at 2016 (33813.2 EGP), also the lowest value recorded at 2015 (17614.7 EGP). The results agreed with GAFRD (2017) reporting that Kafr El-Sheikh Governorate is considered a good example for fish production and intensification where its production constituted about $29 \%$ of the total fish production in Egypt. Also agreed with Al-Faitiany et al. (2006) who found that fixed cost at private farms were 189.4 pounds/ feddan, while at cages were 865.9 pounds/feddan and representing 11.9 $\%$ and $19.4 \%$ from total cost; respectively, and the rent of lands constituted the major part of the fixed cost representing $73.7 \%$, while the nets represented $48.7 \%$ at cages.

\section{2-Effect on TC, TR and NP (EGP) $/ 1000$ fingerlings}

Data at Table (12) showed the effect on TC and TR (EGP) per 1000 fingerlings which differed significantly $(\mathrm{P}<0.05)$ among the different localities, years; as for the NP/1000 fingerlings (EGP) it was non-significantly different $(\mathrm{P}>0.05)$ among different governorates; but significantly different among years. The highest mean value of TC/1000 was in El Sharkia (4383.4 EGP), while the lowest value found in Kafr 
El Sheihk (3881.7 EGP), the highest value recorded at 2016 (4284.8 EGP), also the lowest value recorded at 2015 (3118.2 EGP). Also for TR/1000 fingerlings, it was found that the highest mean value in El Sharkia (6811.1 EGP), while the lowest value found in Kafr El Sheikh (6013.3 EGP), the highest value recorded at 2016 (6806.4 EGP), also the lowest value recorded at 2015 (4291.8 EGP). Finally for NP/1000 fingerlings found the highest mean value in Ismailia (2435.7 EGP), while the lowest value found in Kafr El Sheikh (2131.4 EGP), the highest value recorded at 2016 (2521.6 EGP), also the lowest value recorded at 2015 (1173.9 EGP). This agreed with Aamer (1986) who found that increasing the production of farm will decrease the costs per ton produced.

13-Effect on TC, TR and NP (EGP)/kg

Data at Table (13) showed the effect on TC, TR, and NP (EGP) per $\mathrm{kg}$ body weight which differed significantly $(\mathrm{P}<0.05)$ among the different localities and years. The highest mean value of $\mathrm{TC} / \mathrm{Kg}$ in $\mathrm{El}$ Sharkia (16.34 EGP), while the lowest value found in Kafr El Sheihk (13.12 EGP), the highest value recorded at 2016 (15.53 EGP), also the lowest value recorded at 2015 (11.56 EGP).

And also for TR/Kg found the highest mean value in El Sherkia (25.35 EGP), while the lowest value found in Kafr El Sheikh (20.28 EGP), the highest value recorded at $2016(24.58$ EGP), also the lowest value recorded at 2015 (15.93 EGP). El-Naggar et al. (2006) stated that in season 20042005 , the average fish sales value (revenue) was 18869 LE per feddan in Behera governorate.

Finally, for NP/kg found the highest mean value in El Sharkia (9.01 EGP), while the lowest value found in Kafr El Sheikh (7.16 EGP), the highest value recorded at 2016 (9.06 EGP), also the lowest value recorded at 2015 (4.37 EGP) and the highest mean value found in El Sharkia and Ismailia the same (9.34 EGP) at 2016, and the lowest value found in Ismailia (2.67 EGP) at 2015. This is parallel with Trimpey and Engle (2005) who reported increased size of the farm and increased the market price will increase net revenue.

Table 1: Means $\pm S E$ of pond size, total farm area, and rent / feddan among governorates and years

\begin{tabular}{|c|c|c|c|c|c|}
\hline \multicolumn{2}{|c|}{ Effects } & No. & Pond size & Total farm area & Rent \\
\hline \multirow{3}{*}{ Governorate } & El Sharkia & 35 & $5.30^{\mathrm{A}} \pm 0.46$ & $37.42^{\mathrm{B}} \pm 5.64$ & $3111.42^{\mathrm{B}} \pm 401.11$ \\
\cline { 2 - 7 } & Ismailia & 17 & $4.29^{\mathrm{A}} \pm 0.36$ & $53.47^{\mathrm{AB}} \pm 9.77$ & $2647.06^{\mathrm{B}} \pm 436.56$ \\
\cline { 2 - 7 } & Kafr El-Sheikh & 12 & $4.33^{\mathrm{A}} \pm 0.28$ & $66.67^{\mathrm{A}} \pm 15.95$ & $6416.67^{\mathrm{A}} \pm 583.12$ \\
\hline \multirow{2}{*}{ Year } & 2015 & 7 & $6.64^{\mathrm{A}} \pm 1.63$ & $85.71^{\mathrm{A}} \pm 27.66$ & $3928.57^{\mathrm{A}} \pm 941.13$ \\
\cline { 2 - 7 } & 2016 & 57 & $4.63^{\mathrm{B}} \pm 0.23$ & $42.43^{\mathrm{B}} \pm 4.41$ & $3568.42^{\mathrm{A}} \pm 340.0$ \\
\hline \multicolumn{2}{|c|}{ Overall } & $\mathbf{6 4}$ & $\mathbf{4 . 8 5} \pm \mathbf{0 . 2 8}$ & $\mathbf{4 7 . 1 7} \pm \mathbf{5 . 1 3}$ & $\mathbf{3 6 0 7 . 8} \pm \mathbf{3 1 7 . 7}$ \\
\hline
\end{tabular}

Capital letters: Means within the same column carrying different letters are significantly different at $(\mathrm{P}<0.05)$. 
Table 2: Means \pm SE of stocking density/feddan and total number of fingerlings among governorates and years

\begin{tabular}{|c|c|c|c|c|c|c|}
\hline & Effects & No. & $\begin{array}{c}\text { Tilapia } \\
\text { (Oreochromis } \\
\text { niloticus })\end{array}$ & $\begin{array}{c}\text { Mullet } \\
(\text { Mugil } \\
\text { cephalus })\end{array}$ & $\begin{array}{c}\text { Topar } \\
(\text { Liza } \\
\text { ramada })\end{array}$ & Total No. $\left(\times \mathbf{1 0}^{\mathbf{3}}\right)$ \\
\hline \multirow{4}{*}{ Governorate } & El Sharkia & 35 & $9428^{\mathrm{B}} \pm 645$ & $1032^{\mathrm{A}} \pm 177$ & $1900^{\mathrm{A}} \pm 293$ & $487.55^{\mathrm{B}} \pm 73.19$ \\
\cline { 2 - 7 } & Ismailia & 17 & $10117^{\mathrm{B}} \pm 726$ & $658^{\mathrm{A}} \pm 146$ & $1470^{\mathrm{A}} \pm 90$ & $710.05^{\mathrm{B}} \pm 154.98$ \\
\cline { 2 - 7 } & Kafr El-sheikh & 12 & $14166^{\mathrm{A}} \pm 705$ & $633^{\mathrm{A}} \pm 124$ & $1541^{\mathrm{A}} \pm 143$ & $\begin{array}{c}1108.58^{\mathrm{A}} \pm \\
268.46\end{array}$ \\
\hline \multirow{3}{*}{ Year } & 2015 & 7 & $11285^{\mathrm{A}} \pm 836$ & $871^{\mathrm{A}} \pm 363$ & $1428^{\mathrm{A}} \pm 639$ & $\begin{array}{c}1205.42^{\mathrm{A}} \pm \\
413.87\end{array}$ \\
\hline & 2016 & 57 & $10403^{\mathrm{A}} \pm 523$ & $857^{\mathrm{A}} \pm 114$ & $1754^{\mathrm{A}} \pm 170$ & $596.50^{\mathrm{B}} \pm 71.65$ \\
\hline & Overall & $\mathbf{6 4}$ & $\mathbf{1 0 5 0 0} \pm \mathbf{4 7 5}$ & $\mathbf{8 5 8} \pm \mathbf{1 0 8}$ & $\mathbf{1 7 1 8} \pm \mathbf{1 6 5}$ & $\mathbf{6 6 3 . 1 0} \pm \mathbf{8 0 . 1 2}$ \\
\hline
\end{tabular}

Capital letters: Means within the same column carrying different letters are significantly different at $(\mathrm{P}<0.05)$.

Table 3: Means \pm SE of price (EGP)/1000 fingerlings among governorates and years

\begin{tabular}{|c|l|c|c|c|c|c|}
\hline \multicolumn{2}{|c|}{ Effects } & No. & $\begin{array}{c}\text { Tilapia } \\
\text { (Oreochromis } \\
\text { niloticus) }\end{array}$ & $\begin{array}{c}\text { Mullet } \\
\text { (Mugil } \\
\text { cephalus) }\end{array}$ & $\begin{array}{c}\text { Topar } \\
\text { (Liza ramada) }\end{array}$ & $\begin{array}{c}\text { Fingerlings } \\
\text { cost }\end{array}$ \\
\hline \multirow{5}{*}{ Governorate } & El Sharkia & 35 & $\begin{array}{c}141.28^{\mathrm{A}} \pm \\
10.64\end{array}$ & $\begin{array}{c}1871.42^{\mathrm{B}} \pm \\
158.71\end{array}$ & $\begin{array}{c}574.28^{\mathrm{B}} \pm \\
78.26\end{array}$ & $\begin{array}{c}215277^{\mathrm{A}} \\
\pm 45990\end{array}$ \\
\cline { 2 - 7 } & Ismailia & 17 & $102.35^{\mathrm{AB}}$ & $2382.35^{\mathrm{A}} \pm 80.52$ & $1223.52^{\mathrm{A}} \pm$ & $236675^{\mathrm{A}}$ \\
& Kafr & 12 & $82.50^{\mathrm{B}} \pm$ & $2708.33^{\mathrm{A}} \pm 96.41$ & $1008.33^{\mathrm{A}} \pm$ & $259370^{\mathrm{A}}$ \\
& Elsheikh & & 19.91 & & 56.86 & \pm 50225 \\
\hline \multirow{3}{*}{ Year } & 2015 & 7 & $106.42^{\mathrm{B}} \pm$ & $1628.57^{\mathrm{B}} \pm$ & $571.42^{\mathrm{B}} \pm$ & $264214^{\mathrm{A}}$ \\
& & & 18.52 & 188.60 & 151.94 & \pm 78385 \\
\cline { 2 - 7 } & 2016 & 57 & $121.57^{\mathrm{A}} \pm$ & $2229.82^{\mathrm{A}} \pm$ & $859.64^{\mathrm{A}} \pm$ & $224932^{\mathrm{A}}$ \\
& & 9.13 & 107.02 & 60.92 & \pm 28921 \\
\hline Overall & & $\mathbf{6 4}$ & $\mathbf{1 1 9 . 9 2} \pm \mathbf{8 . 3 7}$ & $\mathbf{2 1 6 4 . 0 6} \pm \mathbf{1 0 0 . 0 5}$ & $\mathbf{8 2 8 . 1 2} \pm \mathbf{5 7 . 5 0}$ & $\mathbf{2 2 9 2 2 8} \pm$ \\
& & & & & $\mathbf{2 6 9 9 2}$ \\
\hline
\end{tabular}

Capital letters: Means within the same column carrying different letters are significantly different at $(\mathrm{P}<0.05)$.

Table 4: Means \pm SE of fuel and transportation costs among governorates and years

\begin{tabular}{|c|l|c|c|c|}
\hline \multicolumn{2}{|c|}{ Effects } & No. & Fuel & Transportation \\
\hline \multirow{3}{*}{ Governorate } & El Sharkia & 35 & $25357.1^{\mathrm{B}} \pm 2634.1$ & $11411.4^{\mathrm{A}} \pm 1588.2$ \\
\cline { 2 - 5 } & Ismailia & 17 & $19970.5^{\mathrm{B}} \pm 3204.8$ & $1341.2^{\mathrm{B}} \pm 299.5$ \\
\cline { 2 - 5 } & Kafr El-sheikh & 12 & $47816.6^{\mathrm{A}} \pm 7220.1$ & $10395.8^{\mathrm{A}} \pm 1896.3$ \\
\hline \multirow{2}{*}{ Year } & 2015 & 7 & $43571.4^{\mathrm{A}} \pm 10505.9$ & $15000^{\mathrm{A}} \pm 4710.5$ \\
\cline { 2 - 5 } & 2016 & 57 & $26242.1^{\mathrm{B}} \pm 2339.9$ & $7753.5^{\mathrm{B}} \pm 1040.1$ \\
\hline Overall & $\mathbf{6 4}$ & $\mathbf{2 8 1 3 7 . 5} \pm \mathbf{2 4 3 8 . 9}$ & $\mathbf{8 5 4 6 . 1} \pm \mathbf{1 0 8 1 . 2}$ \\
\hline
\end{tabular}

Capital letters: Means within the same column carrying different letters are significantly different at $(\mathrm{P}<0.05)$. 
Table 5: Means \pm SE of total feed (tons) and feed cost among governorates and years

\begin{tabular}{|c|l|c|c|c|}
\hline \multicolumn{2}{|c|}{ Effects } & No. & Total feed (Ton) & Feed cost (EGP) \\
\hline \multirow{3}{*}{ Governorate } & El Sharkia & 35 & $187.91^{\mathrm{B}} \pm 26.87$ & $1442697^{\mathrm{B}} \pm 200870$ \\
\cline { 2 - 5 } & Ismailia & 17 & $253.06^{\mathrm{B}} \pm 51.66$ & $2093741^{\mathrm{B}} \pm 447385$ \\
\cline { 2 - 5 } & Kafr El-sheikh & 12 & $397.71^{\mathrm{A}} \pm 106.23$ & $3287479^{\mathrm{A}} \pm 887933$ \\
\hline \multirow{3}{*}{ Year } & 2015 & 7 & $438.86^{\mathrm{A}} \pm 157.61$ & $3232285^{\mathrm{A}} \pm 325945$ \\
\cline { 2 - 5 } & 2016 & 57 & $220.69^{\mathrm{B}} \pm 25.83$ & $1805469^{\mathrm{B}} \pm 217080$ \\
\hline Overall & $\mathbf{6 4}$ & $\mathbf{2 4 4 . 5 5} \pm \mathbf{2 9 . 3 7}$ & $\mathbf{1 9 6 1 5 2 7} \pm \mathbf{2 4 2 6 2 2}$ \\
\hline
\end{tabular}

Capital letters: Means within the same column carrying different letters are significantly different at $(\mathrm{P}<0.05)$.

Table 6: Means \pm SE of total labour cost (EGP) among governorates and years.

\begin{tabular}{|c|l|c|c|}
\hline \multirow{3}{*}{ Eovernorate } & No & Total labor cost \\
\hline \multirow{2}{*}{ Year } & El Sharkia & 35 & $67691^{\mathrm{B}} \pm 5430$ \\
\cline { 2 - 4 } & Ismailia & 17 & $75083^{\mathrm{AB}} \pm 1158$ \\
\cline { 2 - 4 } & Kafr El-sheikh & 12 & $95940^{\mathrm{A}} \pm 16132$ \\
\hline & 2015 & 7 & $107077^{\mathrm{A}} \pm 27685$ \\
\cline { 2 - 4 } & 2016 & 57 & $71006^{\mathrm{B}} \pm 4775$ \\
\hline Overall & $\mathbf{6 4}$ & $\mathbf{7 4 9 5 1} \pm \mathbf{5 2 9 6}$ \\
\hline
\end{tabular}

Capital letters: Means within the same column carrying different letters are significantly different at $(\mathrm{P}<0.05)$.

Table 7: Means \pm SE of cost parameters (TFC, TVC and TC (EGP) among governorates and years

\begin{tabular}{|l|l|c|c|c|c|}
\hline \multicolumn{2}{|c|}{ Effects } & No. & TFC & TVC & TC \\
\hline \multirow{4}{*}{ Governorate } & $\begin{array}{l}\text { El } \\
\text { Sharkia }\end{array}$ & 35 & $172483^{\mathrm{B}} \pm 25536$ & $\begin{array}{c}1727182^{\mathrm{B}} \pm \\
235717\end{array}$ & $1899666^{\mathrm{B}} \pm 254931$ \\
\cline { 2 - 7 } & Ismailia & 17 & $215760^{\mathrm{B}} \pm 43029$ & $2385988^{\mathrm{B}} \pm$ & $2601748^{\mathrm{B}} \pm 526251$ \\
& & & & 496701 & \\
\cline { 2 - 7 } & Kafr & 12 & $528708^{\mathrm{A}} \pm 124920$ & $3720502^{\mathrm{A}}$ & $4249210^{\mathrm{A}} \pm 1007806$ \\
& Elsheikh & & & \pm 956995 & \\
\hline Year & 2015 & 7 & $496347^{\mathrm{A}} \pm 194879$ & $3640605^{\mathrm{A}}$ & $4136953^{\mathrm{A}} \pm 1063636$ \\
& & & & \pm 1045781 & \\
\cline { 2 - 7 } & 2016 & 57 & $220612^{\mathrm{B}} \pm 27606$ & $2108333^{\mathrm{B}} \pm$ & $2328946^{\mathrm{B}} \pm 264136$ \\
& & & & 242347 & \\
\hline Overall & & $\mathbf{6 4}$ & $\mathbf{2 5 0 7 7 1} \pm \mathbf{3 3 4 1 4}$ & $\mathbf{2 2 7 5 9 2 5} \pm$ & $\mathbf{2 5 2 6 6 9 6} \pm \mathbf{2 9 6 9 5 1}$ \\
& & & $\mathbf{2 6 8 1 4 2}$ & \\
\hline
\end{tabular}

Capital letters: Means within the same column carrying different letters are significantly different at $(\mathrm{P}<0.05)$. 
Table 8: Means \pm SE of \% of mortality among governorates and years

\begin{tabular}{|c|l|c|c|}
\hline \multirow{4}{*}{ Effects } & No. of farms & \% mort \\
\hline \multirow{3}{*}{ Governorate } & El Sharkia & 35 & $6.86^{\mathrm{A}} \pm 0.93$ \\
\cline { 2 - 4 } & Ismailia & 17 & $7.65^{\mathrm{A}} \pm 0.62$ \\
\cline { 2 - 4 } & Kafr El-sheikh & 12 & $7.50^{\mathrm{A}} \pm 1.45$ \\
\hline \multirow{2}{*}{ Year } & 2015 & 7 & $9.0^{\mathrm{A}} \pm 1.81$ \\
\cline { 2 - 4 } & 2016 & 57 & $6.96^{\mathrm{B}} \pm 0.82$ \\
\hline Overall & $\mathbf{6 4}$ & $\mathbf{7 . 1 9} \pm \mathbf{0 . 7 5}$ \\
\hline
\end{tabular}

Capital letters: Means within the same column carrying different letters are significantly different at $(\mathrm{P}<0.05)$.

Table 9: Means \pm SE of tilapia, mullet, topar and Total production ( $\mathrm{kg}$ ) among governorates and years

\begin{tabular}{|c|c|c|c|c|c|c|}
\hline \multicolumn{2}{|c|}{ Effects } & No. & Tilapia (kg) & Mullet (kg) & Topar (kg) & Total wt (kg) \\
\hline \multirow{3}{*}{ Governorate } & El Sharkia & 35 & $94848^{C} \pm 13900$ & $14754^{\mathrm{A}} \pm 3098$ & $28276^{\mathrm{A}} \pm 5141$ & $126648^{\mathrm{B}} \pm 17960$ \\
\hline & Ismailia & 17 & $173802^{\mathrm{B}} \pm 4120$ & $10332^{\mathrm{A}} \pm 2607$ & $\begin{array}{l}17041^{\mathrm{B}} \\
\pm 3065\end{array}$ & $201176^{\mathrm{B}} \pm 44842$ \\
\hline & $\begin{array}{l}\text { Kafr } \\
\text { Elsheikh }\end{array}$ & 12 & $295075^{\mathrm{A}} \pm 7315$ & $10945^{\mathrm{A}} \pm 2421$ & $\begin{array}{l}19750^{\mathrm{B}} \\
\pm 2379\end{array}$ & $325770^{\mathrm{A}} \pm 32587$ \\
\hline \multirow[b]{2}{*}{ Year } & 2015 & 7 & $293614^{\mathrm{A}} \pm 17246$ & $19195^{\mathrm{A}} \pm 6740$ & $29220^{\mathrm{A}} \pm 2748$ & $333681^{\mathrm{A}} \pm 60169$ \\
\hline & 2016 & 57 & $136139^{\mathrm{B}} \pm 18705$ & $11831^{\mathrm{B}} \pm 1841$ & $21935^{\mathrm{A}} \pm 2791$ & $165371^{\mathrm{B}} \pm 20673$ \\
\hline \multicolumn{2}{|l|}{ Overall } & 64 & $153363 \pm 21413$ & $12705 \pm 1739$ & $22635 \pm 2400$ & $183780 \pm 12318$ \\
\hline
\end{tabular}

Capital letters: Means within the same column carrying different letters are significantly different at $(\mathrm{P}<0.05)$.

Table 10: Means \pm SE of TR and NP (EGP) among different governorates and years

\begin{tabular}{|c|l|c|c|c|}
\hline \multicolumn{2}{|c|}{ Effects } & No. & TR (EGP) & NP (EGP) \\
\hline \multirow{3}{*}{ Governorate } & El Sharkia & 35 & $3178739^{\mathrm{B}} \pm 247653$ & $1279072^{\mathrm{B}} \pm 119643$ \\
\cline { 2 - 5 } & Ismailia & 17 & $4563647^{\mathrm{AB}} \pm 920192$ & $1961898^{\mathrm{A}} \pm 117895$ \\
\cline { 2 - 5 } & Kafr El-sheikh & 12 & $6519045^{\mathrm{A}} \pm 689512$ & $2269835^{\mathrm{A}} \pm 136586$ \\
\hline \multirow{2}{*}{ Year } & 2015 & 7 & $6118785^{\mathrm{A}} \pm 845108$ & $1981832^{\mathrm{A}} \pm 1088334$ \\
\cline { 2 - 5 } & 2016 & 57 & $3933946^{\mathrm{B}} \pm 458785$ & $1605000^{\mathrm{A}} \pm 2105544$ \\
\hline Overall & $\mathbf{6 4}$ & $\mathbf{4 1 7 2 9 1 3} \pm \mathbf{2 9 8 4 0 8}$ & $\mathbf{1 6 4 6 2 1 6} \pm \mathbf{2 1 8 3 0 0}$ \\
\hline
\end{tabular}

Capital letters: Means within the same column carrying different letters are significantly different at $(\mathrm{P}<0.05)$.

Table 11: Means \pm SE of TC, TR and NP (EGP)/fed among governorates and years

\begin{tabular}{|c|l|c|c|c|c|}
\hline \multicolumn{2}{|c|}{ Effects } & No. & TC/fed & TR/fed & NP/fed \\
\hline \multirow{4}{*}{ Governorate } & El Sharkia & 35 & $51392.7^{\mathrm{B}} \pm 2267.4$ & $83128.9^{\mathrm{AB}} \pm 6991.2$ & $31736.2^{\mathrm{A}} \pm 5006.2$ \\
\cline { 2 - 6 } & Ismailia & 17 & $45976.2^{\mathrm{C}} \pm 2016.3$ & $77161.4^{\mathrm{B}} \pm 8716.3$ & $31185.2^{\mathrm{A}} \pm 6241.3$ \\
\cline { 2 - 6 } & Kafr El-sheikh & 12 & $62725.8^{\mathrm{A}} \pm 2264.5$ & $96871.2^{\mathrm{A}} \pm 8968.3$ & $34145.4^{\mathrm{A}} \pm 6422.3$ \\
\hline \multirow{3}{*}{ Year } & 2015 & 7 & $43205.9^{\mathrm{B}} \pm 4191.2$ & $60307.2^{\mathrm{B}} \pm 8913.5$ & $17614.7^{\mathrm{B}} \pm 6382.5$ \\
\cline { 2 - 6 } & 2016 & 57 & $54625.3^{\mathrm{A}} \pm 1614.6$ & $89118.6^{\mathrm{A}} \pm 3434.1$ & $33813.2^{\mathrm{A}} \pm 2459.1$ \\
\hline Overall & $\mathbf{6 4}$ & $\mathbf{5 2 0 7 8 . 9} \pm \mathbf{1 5 6 8 . 4}$ & $\mathbf{8 4 1 2 0 . 5} \pm \mathbf{3 1 3 0 . 6}$ & $\mathbf{3 2 0 4 1 . 5} \pm \mathbf{2 1 1 1 . 3}$ \\
\hline
\end{tabular}

Capital letters: Means within the same column carrying different letters are significantly different at $(\mathrm{P}<0.05)$. 
Table 12: Means $\pm S E$ of TC, TR and NP (EGP) / 1000 fingerlings among governorates and years

\begin{tabular}{|c|l|c|c|c|c|}
\hline \multicolumn{2}{|c|}{ Effects } & No. & TC/1000 & TR/1000 & NP/1000 \\
\hline \multirow{4}{*}{ Governorate } & El Sharkia & 35 & $4383.4^{\mathrm{A}} \pm 279.3$ & $6811.1^{\mathrm{A}} \pm 253.3$ & $2427.6^{\mathrm{A}} \pm 277.1$ \\
\cline { 2 - 6 } & Ismailia & 17 & $3885.8^{\mathrm{B}} \pm 348.2$ & $6321.4^{\mathrm{AB}} \pm 315.8$ & $2435.7^{\mathrm{A}} \pm 345.4$ \\
\cline { 2 - 6 } & Kafr El-sheikh & 12 & $3881.7^{\mathrm{B}} \pm 358.2$ & $6013.3^{\mathrm{B}} \pm 325.2$ & $2131.4^{\mathrm{A}} \pm 355.5$ \\
\hline \multirow{3}{*}{ Year } & 2015 & 7 & $3118.2^{\mathrm{B}} \pm 356.1$ & $4291.8^{\mathrm{B}} \pm 323.4$ & $1173.9^{\mathrm{B}} \pm 353.5$ \\
\cline { 2 - 6 } & 2016 & 57 & $4284.8^{\mathrm{A}} \pm 137.2$ & $6806.4^{\mathrm{A}} \pm 124.5$ & $2521.6^{\mathrm{A}} \pm 136.2$ \\
\hline \multicolumn{2}{|c|}{ Overall } & $\mathbf{6 4}$ & $\mathbf{4 1 5 7 . 2} \pm \mathbf{1 2 4 . 9}$ & $\mathbf{6 5 3 1 . 5} \pm \mathbf{1 4 8 . 6}$ & $\mathbf{2 3 7 4 . 2} \pm \mathbf{1 2 3 . 8}$ \\
\hline
\end{tabular}

Capital letters: Means within the same column carrying different letters are significantly different at $(\mathrm{P}<0.05)$.

Table 13: Means \pm SE of TC, TR and NP (EGP)/kg among governorates and years

\begin{tabular}{|c|l|c|c|c|c|}
\hline \multicolumn{2}{|c|}{ Effects } & No. & TC/kg & TR/kg & NP/kg \\
\hline \multirow{3}{*}{ Governorate } & El Sharkia & 35 & $16.34^{\mathrm{A}} \pm 1.11$ & $25.35^{\mathrm{A}} \pm 1.06$ & $9.01^{\mathrm{A}} \pm 0.98$ \\
\cline { 2 - 6 } & Ismailia & 17 & $13.91^{\mathrm{AB}} \pm 1.39$ & $22.47^{\mathrm{B}} \pm 1.32$ & $8.56^{\mathrm{A}} \pm 1.23$ \\
\cline { 2 - 6 } & Kafr El-sheikh & 12 & $13.12^{\mathrm{B}} \pm 1.43$ & $20.28^{\mathrm{B}} \pm 1.36$ & $7.16^{\mathrm{B}} \pm 1.26$ \\
\hline \multirow{3}{*}{ Year } & 2015 & 7 & $11.56^{\mathrm{B}} \pm 1.42$ & $15.93^{\mathrm{B}} \pm 1.35$ & $4.37^{\mathrm{B}} \pm 1.25$ \\
\cline { 2 - 6 } & 2016 & 57 & $15.53^{\mathrm{A}} \pm 0.55$ & $24.58^{\mathrm{A}} \pm 0.53$ & $9.06^{\mathrm{A}} \pm 0.48$ \\
\hline Overall & $\mathbf{6 4}$ & $\mathbf{1 5 . 0 9} \pm \mathbf{0 . 0 6}$ & $\mathbf{2 3 . 6 3} \pm \mathbf{0 . 5 9}$ & $\mathbf{8 . 5 4} \pm \mathbf{0 . 4 4}$ \\
\hline
\end{tabular}

Capital letters: Means within the same column carrying different letters are significantly different at $(\mathrm{P}<0.05)$.

\section{Conclusion:}

The current study showed that fish farm locality has a notable effect on the productive and economic parameters of fish farms. Regarding total fish production, Kafr El Sheikh governorate had the highest amount of fish production, while El Sharkia was the lowest. From the results of analysis of locality effect on economic parameters (TC, TR and $\mathrm{NP}$ (EGP)/ kg), it is concluded that although El Sharkia governorate had the highest value of total cost (16.34 EGP) and Kafr El Sheikh governorate had the lowest one (13.12 EGP), the highest profit recorded was in El Sharkia governorate (9.01 EGP). One possible explanation to this, is the higher selling price / $\mathrm{kg}$ in El Sharkia governorate.

\section{References}

Aamer, M.G. (1986): Economic studies on fish farms in Egypt. M. V. Sc- Faculty of Agriculture - Zagazig University. Alam, M.F., Khan, M.A., Anwarul
Haq, A.S. (2012): Technical efficiency in tilapia farming of Bangladesh: a stochastic frontier production approach. Aquaculture Int. 20:619-634

Al-Faitiany, A.A. and Fayed, J.M. (2006): Statistical Estimation of the Cost Functions of the Fisheries Sector in Kafr El Sheikh. Egyptian Journal of Agricultural Economics; Volume 16, Issue 4, December 2006 Aly, M. (2006): Maximizing the productive efficiency of fish farms in relation to veterinary practices. M.V.Sc. Thesis. Faculty of 
Veterinary Medicine. Zagazig University.

Azazy, G.E. (2003): An economic analytical study for determination of risk factors in fish culture. Ph.D. Thesis, Department of Agricultural Economics, Faculty of Agriculture, Al-Azhar University.

Bhujel, R.C. (2014): A manual for tilapia business management. CABI Publisher.

CAPMAS (2014): Central Agency for Public Mobilization and Statistics; Egypt in figers report 2014. Ref. No. 71-01112-2014

Craig, S. and Helfrich, L. (2009): Understanding fish nutrition, feeds, and feeding. Viginia Cooperative Extension Service. Publication 420256.

Website:http://pubs.ext.vt.edu14202561

Eissa, I.A., Derwa, H.I, Noor El Deen, A.E., Abd El hady, M.S. (2013): studies on the prevailing ectoparasitic protozoal disease in wild and cultured oreochromis niloticus with reference to control, the Global journal of fisheries and aquaculture research 6,57-64.

El-Naggar, G., Nasr-Alla, A., Kareem, R.O. (2006): Factors influencing fish farm productivity in Egypt (A case study of Behera province). Journal of Egyptian Aquaculture Society. 1: 81-98

El-Sayed, A. (2014): Value chain analysis of the Egyptian aquaculture feed industry. World Fish, Penang, Malaysis. Project Report; 2014-22
GAFRD (General Authority for Fish resources Development) 2009: Extension bulletins series, No. (36)

GAFRD (2017): Fish statistics book 2015.

Hafsa, A., Hala, M. and Nadia, A. (2012): Aquaculture and Its Role in Mitigating The Effects of fish Gap in Egypt. Porceedings of the $5^{\text {th }}$ Global Fisheries \& Aquaculture Research Conference, Egypt, pp: $272-285$ Macfadyen, G., Nasr Allah, A.M., Kenawy, D., Ahmed, M., Hebicha, H., Diab, A., (2011): Value-chain analysis of Egyptian aquaculture. Project report 2011-54. The World Fish center. Penang, Malaysia. 84 pp.

Mandour, M.A. (2013): Effect of Veterinary Management on Aquaculture Economics. $\mathrm{PhD}$ Dissertation. Department of Animal Wealth Development. Faculty of Veterinary Medicine, Suez Canal University.

Rothuis, A., Pieter van Duijn, A., Roem, A., Ouwehand, A., Piji, W., Rurangwa, E., (2013): Aquaculture business opportunities in Egypt. Wageningen, Wageningen UR (University \& Research centre). LEI report 2013-039, IMARES report C091/13

Samuel-Fitwi, B., Nagel, F., Meyer, S., Schroder, J.P., Schulz, C., (2013) Comparative life cycle assessment of raising rainbow trout (Oncorhynchusmykiss) in different production systems. Aquac Eng 54:85-92. 
Schwedler, T.E. and Johansen, S.K. (2000): Responsible care and health maintenance of fish in commercial aquaculture. Animal Welfare information center Bulletin, Winter 1999/2000 Vol. 10 No. 3-4.

Sikiru, B.O.; Omobolanle, N.M.; Ayorinde, B.J. and Adegoke, O.O. (2009): Improving Clarias productivity towards achieving food security in Ijebu-Ode State, Nigeria. A socioeconomic Analysis. Advances in Biological Research, 3(1-2): 24-28.

Soliman, N.F. and Yacout, D.M. (2016): Aquaculture in Egypt: status, constraints and potentials.
Aquaculture

24(5):1201-27

Trimpey, J. and Engle, C. (2005): The economic feasibility of adoption of a new in-pond mechanical grader for food-sized channel catfish (Ictalurus punctatus). Aquacultural Engineering, Volume 32 (3-4): 411423.

Yosra, A.A. (2008): Studies on the role of freshwater fishes in transmitting some parasites to man in Suez Canal Area. M.Sc. Thesis, Department of Animal hygiene, Zoonoses and Animal ethology, Faculty of Veterinary Medicine, Suez Canal University

\title{
مقارنة الكفاءة الانتاجية والاقتصادية لبعض مزارع أسماك المياه العذبة بمحافظات

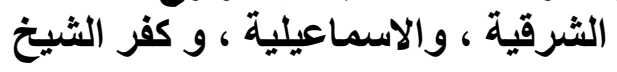

\author{
محمد منصور عثمان1، محمد أبو العطا2،منال محمد2،مصطفى مندور1 1

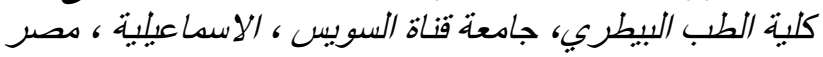

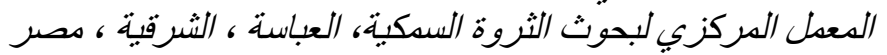

يعتبر الاستزر اع السمكي احد الادوات التي تستخدمها الحكومة لتوفير الاحتياجات من البروتين للاجيال

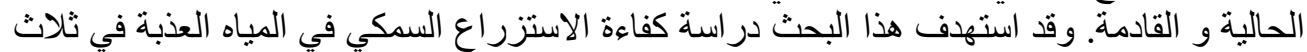

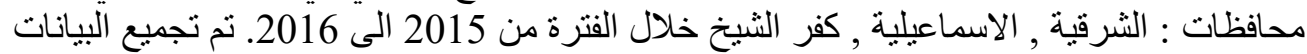

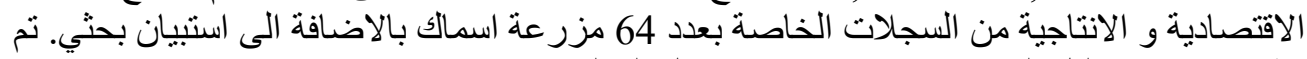

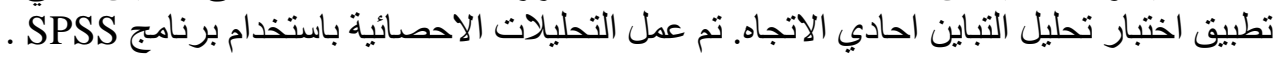

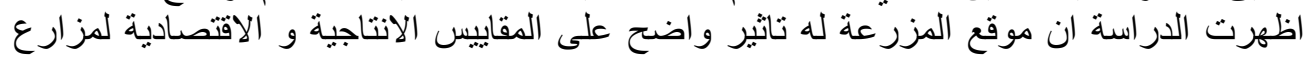

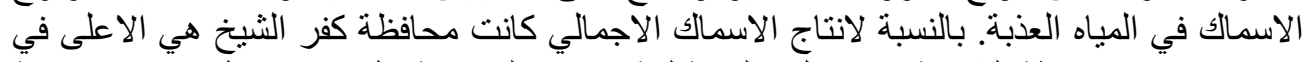

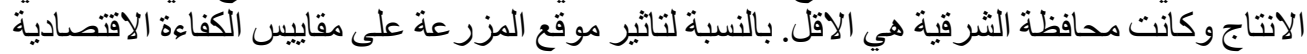

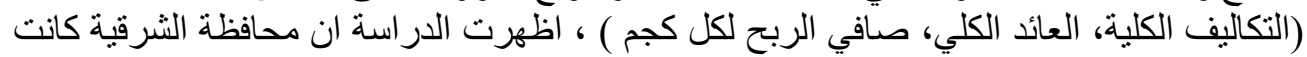

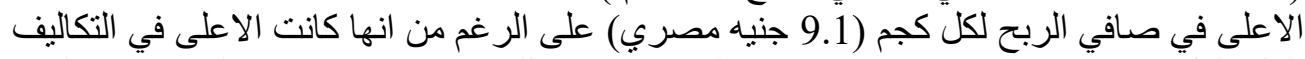

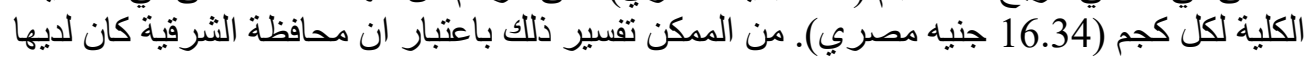

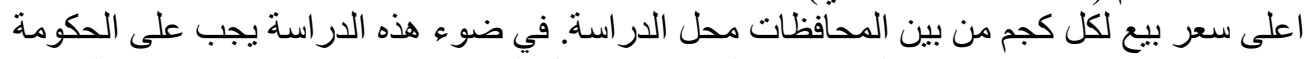

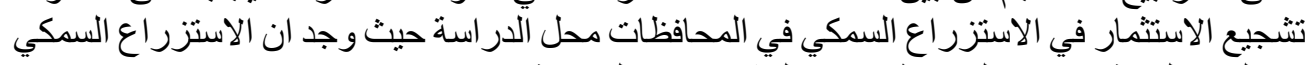
في المياه العذبة في هذه المحافظات من الششرو عات المربحة. 